\title{
My culture is engraved on my tombstone
}

\author{
Erdoğan Bada ${ }^{1}$ \\ Ömer Gökhan Ulum²
}

\begin{abstract}
We, humans, mirror our cultural characteristics in death just as we do in life. This study focuses on the way the dead communicate with the living through their gravestones. For this, we surveyed, photographed and documented a plethora of gravestones affiliated to Shamanism, Taoism, Judaism, Christianity, and Islam, and conducted content analysis of thematized scripts on stones and objects left on graves for remembrance. Our findings suggest that each set of beliefs displays specific as well as common messages concerning the deceased and the society they belonged to. The study asserts that although we, ephemeral creatures, pass in our final hour, our gravestones keep transmitting our cultural identity from generation to generation with information regarding who and what we were.
\end{abstract}

Keywords: Textual analysis; content analysis; culture; language; tombstones.

\section{Introduction}

Depending on cultural characteristics, graveyards or cemeteries are usually viewed as rather frightening and creepy places for the very feeling of loss and death. The reality about these places is that they are indeed the backyards of history founded at a firmly changing cultural prospect (Veit and Nonestied, 2008). The Turkish poet, Beyatlı (n.d.), states that no poem could ever be as national as a tombstone, since a tombstone, hosting the eye-straining effort and art inside introduces to us our own selves. Most of the notions of death seen on tombstones refer to a positive value-judgment of mortality, and focus on supporting those living in handling the regret of loss and the unease of dying (Fernández, 2011). Furthermore, tombstones, a phenomenon of civilization, remove the coldness of death, and have a vital role in a society's development of its identity. They connect the past to our present day, reflecting the characteristics of a dead society with all its architectural, societal, economical, intellectual, political, artistic and cultural layers (Veit and Nonestied, 2008; Vırmiça, 2010). They bring to light all such embedded characteristics in a society concerning a particular era in which they existed (Stone, 1991; Veit and Nonestied, 2008; Stone, 2009; Gürman and Fitton-Brown, 2013). Veit and Nonestied (2008) put it quite rightly by stating that one cannot see a better place to face the thoughts and beliefs of the very first settlers of a land than a burial ground. Similarly, Streiter, Lin, Yen, Hsu, Wang and Goudin (2008) suggest that tombstones are significant products of a culture supplying humans with the opportunity to be able to analyze crucial features in a particular culture. On tombstones, one can see names, parental names, death dates, and occupations concerning the deceased (Farber, 2003; Snell, 2003). Moreover, the script data on tombstones provides us with the chance to make inferences in clarifying diverse points or in making deductions about a particular culture from content of such scripts. Analysis of this content bears great significance in aiding us in our interpretation of

\footnotetext{
1 Prof. Dr., Çukurova University, Faculty of Education; Department of Foreign Language Teaching; erdoganbada@gmail.com

${ }^{2}$ Lecturer, Adana Science and Technology University, School of Foreign Languages, omergokhanulum@gmail.com
} 
potential, embedded messages that may have been running from generation to generation. For this, textual analysis principles were utilized in this study.

Textual analysis is a form of analyzing themes existing in written texts, and as is put by communication researchers, is employed in defining and interpreting features of a written or visual report. One of the major approaches to textual analysis is content analysis which is employed to diagnose, list, and analyze occurrences of particular messages and message features embedded in texts (Frey, Botan and Kreps, 1999; Carley, 1993). It aims to outline content, structure, and functions of themes included in texts (McKee, 2003; Frey, Botan and Kreps, 1999). For some researchers (Bernard and Ryan, 1998), textual analysis covers interpretation and seeks meaning in texts, while for some others (Bernard and Ryan, 1998; Shapiro and Markoff, 1997), it includes the transformation of texts into codes that symbolize messages. When textual analysis is carried out, an academic assumption is made through most probable interpretations that come out of the text (McKee, 2003). In this vein, Condillac (2001) suggests that analyzing is nothing but an operation that results from conjunction of preceding operations; it consists in composing and decomposing ideas in creating new combinations. Therefore, textual analysis is as contextual as it is cultural (Kovala, 2002).

We share the belief with Streiter, Voltmer and Goudin (2007) that tombstone scripts illustrate a linguistic genre which gives way to a deep understanding in culture and language. When transformation occurs, the only remaining evidence of previous existence is the language on the tombstone in a form of either words or symbols, projecting and/or symbolizing statuses, social connections, conceptual systems, mythologies and faiths. Thus, this study, utilizing textual analysis, was conducted in order to shed light on social and cultural messages transmitted through texts engraved on tombstones belonging to different faiths. With this in mind, we sought responses to the following research questions:

1. What is the nature of inscriptions on tombstones (linguistic/nonlinguistic)?

2. How does this nature differ, if it does, regarding diverse faiths?

3. What social and cultural messages are inferred from tombstone inscriptions in diverse faiths?

4. What similarities and differences do such social and cultural messages present regarding diverse faiths?

\section{Data Collection}

The data for this study was collected through scripts belonging to a total of 2008 tombstones reflecting different faiths. Of the tombstones, 1308 were surveyed from different published sources (Seth, 1937; Karamagarali, 1972; Seyirci and Topbas, 1985; Bakırc1, 2005; More Grave Inscriptions, 2006; Chinese Tombstones, 2007; Chinese Cemetery Headstones, 2009; Kut and Eldem, 2010; Sevim, 2010; Chater, 2011; Stoke-on-Trent, 2011; Kaya, 2012; Gürman and Fitton-Brown, 2013; Meier, 2013; Monumental Inscriptions at Tongland Kirkyard 2015; Headstones and Memorial Design Gallery, 2015), and 700 graves representing different faiths in the province of Adana were photographed and added to this data.

\section{Instruments}

The instruments for data collection, as was stated above, consisted of two means: published and photographed. The published material was composed of 1308 tombstones, and the photographed included 700. Both sets of data represented diverse faiths (Shamanism=76, Taoism $=10$, Judaism $=309$, Christianity [Orthodox $=131$, Catholicism $=388$, and Protestantism=184], and Islam [Sunni=728, and Alawite=182]). 
Bada, E., \& Ulum, Ö. G. (2016). My culture is engraved on my tombstone. Journal of Human Sciences, 13(3), 5407-5422. doi:10.14687/jhs.v13i3.4246

\section{Data Analysis and Results}

Tombstone inscriptions were examined with a special focus on the research questions posed in the study. Thus, content analysis was carried out in order to define the nature of the scripts, diversity of this nature, the messages transmitted, and diversity of these messages depending on different faiths. In our thematic analysis, SPSS (v20.0) was utilized for frequency of emerging themes and their significance of dispersion (Chi-square values).

As for the nature of scripts, the data yielded both linguistic and nonlinguistic representation of messages. While the linguistic representation was categorized as affiliation, dwelling, dynasty, faith, grief, heroism, kinship, martyrdom, nicknames, occupation, passing, passing location, personality, praise, race, reasons of passing, social status, untimely passing, and yearning, the nonlinguistic consisted of symbols (pictures, decorations, and signs). The results are presented in tabular forms for all faiths, starting with the oldest (Shamanism) and ending with the most recent (Islam).

\section{Shamanist Tombstone Scripts}

In this group of scripts, we observed both linguistic and nonlinguistic representations. In the former, six themes indicating affiliation (67.2\%), nicknames (13.1\%), kinship (8.2\%), occupation $(8.2 \%)$, faith (1.6\%), and reasons of passing (1.6\%), and in the later we observed pictures and decorations $(76.0 \%)$, and pictures $(24.0 \%)$ only on the gravestones. In Table 1 , we can see the themes and related frequencies pertaining to Shamanist scripts.

Table 1

Expressions of Shamanist Scripts

\begin{tabular}{llllll}
\hline Linguistic & & & Nonlinguistic & \\
\hline Themes & ToM & $\mathbf{0}$ & Symbols & ToM & \% \\
Affiliation & 41 & 67.2 & Pictures and Decorations & 25 & 76.0 \\
Nicknames & 8 & 13.1 & Pictures & 8 & 24.0 \\
Kinship & 5 & 8.2 & Decorations & - & - \\
Occupation & 5 & 8.2 & Signs & - & - \\
Faith & 1 & 1.6 & & & \\
Reasons of Passing & 1 & 1.6 & & 33 & 100.0 \\
Total & 61 & 100.0 & Total & & \\
\hline Chi-Square (Asymp. Sig) & 0.000 & & 0.000 & &
\end{tabular}

As can be observed from Table 1, the expression of affiliation on the Shamanist tombstone scripts emerged as the strongest linguistic theme, followed by nicknames, kinship, occupation, faith, and reasons of passing. As for the nonlinguistic representations, pictures and decorations had a significant occurrence followed by pictures only. Samples from tombstone scripts reflecting these expressions, and symbols are presented below:

Affiliation and nickname: Sara Reamer, Kaasoot, Tlingit Tribe, Chookaneidei Clan, Iceberg House, 1925-2004 Kaasoot will be honored in the halls of eternity, by past, present and future generations.

Family and faith: Great Spirit, Whose voice I hear in the wind, Whose breath gives Life to the world, Hear me I come to you as one of Your many children, I am small and weak, I need your strength and wisdom. May I walk in beauty (American Indian Prayer) Harold Thomas Black, Aug. 11 1960, Jun. 212005 In Loving Memory, Beloved husband, father, son, brother, uncle and grandfather".

Occupation, reasons of passing, nicknames: A'kavehe Onahe, Limber Bones, a Cheyenne Warrior fell here on June 25, 1876 while defending the Cheyenne way of life. 
Bada, E., \& Ulum, Ö. G. (2016). My culture is engraved on my tombstone. Journal of Human Sciences, 13(3), 5407-5422. doi: $10.14687 /$ jhs.v13i3.4246

Decorations and pictures:

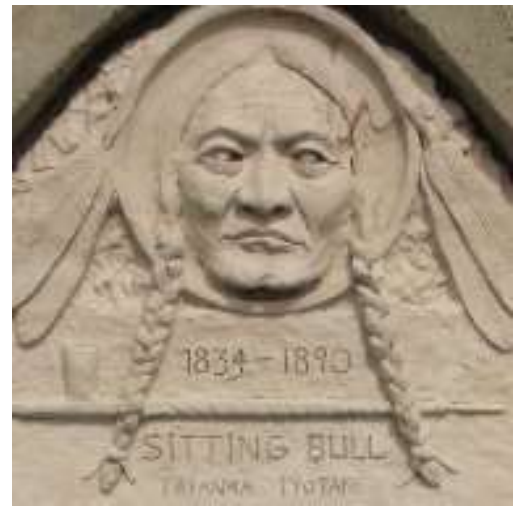

Figure 1.Sitting Bull Monument. Reprinted from Indian Art, Monuments Memorials, Native American Indians. Retrieved from https://in.pinterest.com/pin/161425967868459218/

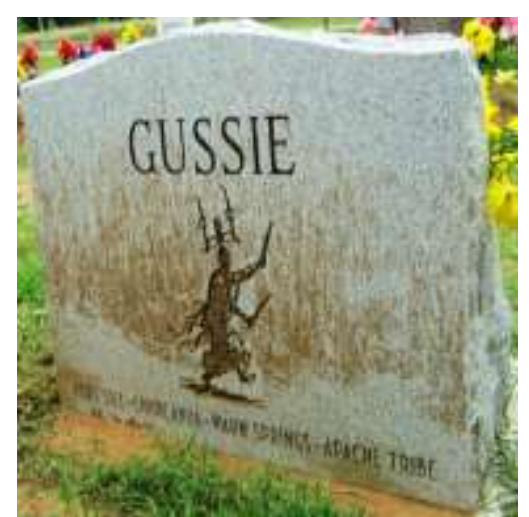

Figure 2. Apache Grave. Reprinted from Finding Hidden Stories in Tombstone Art, by Allison Meier. Retrieved from http://hyperallergic.com/73763/findinghidden-stories-in-tombstone-art/ Copyright 2014 Hyperallergic Media, Inc.

\section{Taoist Tombstone Scripts}

In the Taoist tombstone scripts, we observed three linguistic and no nonlinguistic representations. Out of the total 19 occurrences of the linguistic themes, nine $(47.0 \%)$ reflected dwelling; six (32.0\%), kinship; and four (21.0\%), dynasty. No nonlinguistic representations were detected. From Table 2, we can see the themes and their pertaining percentages.

Table 2

Expressions of Taoist Scripts

\begin{tabular}{llllll}
\hline Linguistic & & & Nonlinguistic & \\
\hline Themes & ToM & $\mathbf{0}$ & Symbols & ToM & $\mathbf{\%}$ \\
Dwelling & 9 & 47.0 & Pictures and Decorations & - & - \\
Kinship & 6 & 32.0 & Pictures & - & - \\
Dynasty & 4 & 21.0 & Decorations & - & - \\
& & & Signs & - & - \\
Total & 19 & 100.0 & Total & - & - \\
\hline Chi-Square (Asymp. Sig) & 0.368 & & 0.000 & & \\
\hline
\end{tabular}

Due to a rather limited number of tombstones in this group, the data here does not probably present a generalizable outcome about Taoist tombstone inscriptions. However, when the ten pieces available to us are examined, we can see that all, dwelling, kinship, and dynasty are reflected with no significant differences of occurrence $(p=0.368)$. Samples representing the themes are illustrated below:

Dynasty and dwelling: Chan Potong, 1885-1963, Guangdong Province, Xinhui County, Yaxi Municipality, Wangchong Village, Born in the 15th year of the reign of the Qing Dynasty, i.e. 1885.

Kinship: Chang, in loving memory of Kuo Tao, Nov. 26. 1897 - Dec. 3. 1979. Beloved husband of Tze Li Young, Dec.9. 1902-Mar. 27.1994. 
Bada, E., \& Ulum, Ö. G. (2016). My culture is engraved on my tombstone. Journal of Human Sciences, 13(3), 5407-5422. doi: $10.14687 /$ jhs.v13i3.4246

\section{Judaist Tombstone Scripts}

In Judaist tombstone scripts, we observed both linguistic and nonlinguistic representations. In the linguistic category, 10 themes, with a total of 334 occurrences, emerged from our analysis: kinship (86.5\%), yearning (6.6\%), occupation (3.0\%), personality $(0.9 \%)$, reasons of passing $(0.9 \%)$, affiliation $(0.6 \%)$, faith $(0.6 \%)$, grief $(0.3 \%)$, social status $(0.3 \%)$, and untimely passing $(0.3 \%)$. As for nonlinguistic representations, we detected 115 symbols in total: signs (81.0\%), and pictures and signs $(19.0 \%)$. In Table 3, we can see both the linguistic and nonlinguistic representations with their pertaining frequency of emergence.

Table 3

Expressions of Judaist Scripts

\begin{tabular}{|c|c|c|c|c|c|}
\hline Linguistic & & & Nonlinguistic & & \\
\hline Themes & ToM & $\%$ & Symbols & ToM & $\%$ \\
\hline Kinship & 289 & 86.5 & Signs & 93 & 81.0 \\
\hline Yearning & 22 & 6.6 & Pictures and Signs & 22 & 19.0 \\
\hline Occupation & 10 & 3.0 & Decorations & - & - \\
\hline Personality & 3 & 0.9 & Pictures & - & - \\
\hline Reasons of Passing & 3 & 0.9 & & & \\
\hline Affiliation & 2 & 0.6 & & & \\
\hline Faith & 2 & 0.6 & & & \\
\hline Grief & 1 & 0.3 & & & \\
\hline Social Status & 1 & 0.3 & & & \\
\hline Untimely Passing & 1 & 0.3 & & & \\
\hline Total & 334 & 100.0 & Total & 115 & 100.0 \\
\hline Chi-Square (Asymp. Sig) & 0.000 & & 0.000 & & \\
\hline
\end{tabular}

From Table 3, we can clearly see that the theme kinship, has predominantly topped the list of linguistic themes, followed by yearning, occupation, personality, reasons of passing, affiliation, faith, grief, social status, untimely passing respectively. Samples from tombstone scripts reflecting these expressions, and symbols are presented below:

Kinship: Lein Marian, Beloved \& Adored wife, mother, grandmother, great grandmother and sister, 1926-2002.

Yearning: In ever loving memory of Miriam, Darling daughter of Minnie Abrams, Who passed away $30^{\text {th }}$ March 1928, age 32 years. Sadly missed and always remembered by her heartbroken mother, uncles, aunts, cousins and a large circle of friends.

Occupation and faith: Edward I. Koch, Mayor of the city of New York 1978-1989, my father is Jewish, my mother is Jewish, I am Jewish. Hear, O Israel, the Lord our God, the Lord is One.

Personality: In loving memory of Michael Winner, 30th October 1935-21st January 2013, Adored husband, film director and raconteur, -Never a loser be only a winner he.

Reasons of passing: Here lieth, a third of the ashes of 344, cremated sacred souls, victims of the Nazis, including the remains of Schmul, Son of Y'cheel Szcerkowski who was killed on the third of Mar.17, 1945. Brought here from Alem, Hanover, Germany.

Grief: In loving memory of our dear mother Rose Levy who died July 5th 1941, in her $71^{\text {st }}$ year. Deeply mourned by her son, daughters, sons in law, grandchildren and relatives. 
Bada, E., \& Ulum, Ö. G. (2016). My culture is engraved on my tombstone. Journal of Human Sciences, 13(3), 5407-5422. doi:10.14687/jhs.v13i3.4246

Social status and affiliation: Chief rabbi, Gaston Mizrahi, The spiritual leader of Adana Jewish Community, 1887-1963.

Untimely passing: In loving memory of Samuel Robert Copeland who departed this life with tragic suddenness on 17th November 1954. In his 53rd year, so sadly missed and always in the thoughts of his wife, son, daughter, son-in-law, grandson, relatives \& friends. May his dear soul rest in peace.

Pictures and signs:

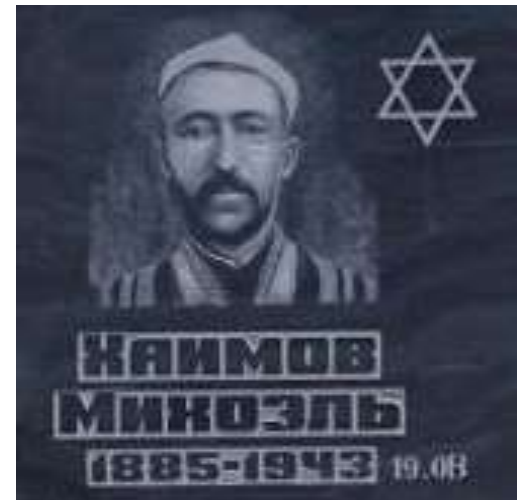

Figure 3. Three men on one gravestone at the Jewish Cemetery. Reprinted from Bukhara Jewish Cemetery | Uzbekistan | Asia.

Retrieved from

http://www.traveladventures.org/continents/

asia/bukhara- jewish-cemetery09.html

Copyright 2016 www.traveladventures.org

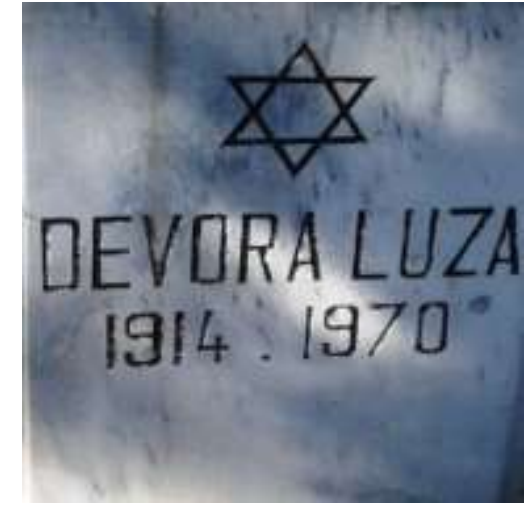

Figure 4. Bada \& Ulum (photographers). (2015). Devora Luza's (1914-1970) Tombstone. Adana, Asri Cemetary.

\section{Orthodox Tombstone Scripts}

Both linguistic and nonlinguistic representations were observed in the Orthodox tombstone scripts. In the former, a total of 266 occurrences of 11 themes emerged with varying frequencies: kinship (38.3\%), race (22.6\%), passing location (16.5\%), faith (13.2\%), dwelling (3.0\%), occupation (2.3\%), personality $(1.9 \%)$, nicknames $(0.8 \%)$, reasons of passing $(0.8 \%)$, grief $(0.4 \%)$, and untimely passing $(0.4 \%)$. As for the nonlinguistic categories, both signs $(81.0 \%)$, and signs and pictures $(19.0 \%)$ were observed.

Table 4

Expressions of Orthodox Scripts

\begin{tabular}{|c|c|c|c|c|c|}
\hline \multicolumn{3}{|l|}{ Linguistic } & \multicolumn{3}{|l|}{ Nonlinguistic } \\
\hline Themes & ToM & $\%$ & Symbols & ToM & $\%$ \\
\hline Kinship & 102 & 38.3 & Signs & 39 & 81.0 \\
\hline Race & 60 & 22.6 & Pictures and Signs & 9 & 19.0 \\
\hline Passing location & 44 & 16.5 & Pictures & - & - \\
\hline Faith & 35 & 13.2 & Decorations & - & - \\
\hline Dwelling & 8 & 3.0 & & & \\
\hline Occupation & 6 & 2.3 & & & \\
\hline Personality & 5 & 1.9 & & & \\
\hline Nicknames & 2 & 0.8 & & & \\
\hline Reasons of passing & 2 & 0.8 & & & \\
\hline Grief & 1 & 0.4 & & & \\
\hline Untimely passing & 1 & 0.4 & & & \\
\hline Total & 266 & 100.0 & Total & 48 & 100.0 \\
\hline Chi-Square (Asymp. Sig) & 0.000 & & 0.000 & & \\
\hline
\end{tabular}


Bada, E., \& Ulum, Ö. G. (2016). My culture is engraved on my tombstone. Journal of Human Sciences, 13(3), 5407-5422. doi:10.14687/jhs.v13i3.4246

From Table 4, supremacy of kinship in the linguistic category is rather conspicuous. With decreasing frequencies, other themes are race, passing location, faith, dwelling, occupation, personality, nicknames, reasons of passing, grief, and untimely passing. Samples from tombstone scripts reflecting these themes, and symbols are presented below:

Kinship and grief: In loving memory of Phelomina Reghelini, granddaughter of Colonel David Jacob of Scindia's Army and Major Reghelini of Samru Begum's Army. Died on 5th July 1927. Aged 76 years. Deeply mourned by her sorrowing son.

Race, occupation, faith, and personality: Tomb of Khoja Morteneous, Armenian merchant died 1611. Here lies the holy Khoja Mortenepus, Armenian, who was a professed disciple of Christ, and who was a righteous man; whatever he had, he gave in charity to the poor, in token of fidelity to his Divine Master, in the year one thousand six hundred and eleven from the birth of Christ.

Passing location and nicknames: This is the tomb of Aaria, the son of Arathoon of Kars, who was called Haghverdibeg. He departed to the Lord at Agra on the 22nd September 1786.

Dwelling: This is the tomb of Manook who is from the city of Venice. Died in the year 63 of the era of Azaria (1678 A.D.).

Reasons of passing: This is the tomb of Agah Samuel of the Delakhian family who was murdered by the Jats in the year 1104 of the Armenian era (1655 A.D.).

Untimely passing: This is the tomb of Kirakose who departed to Christ in his young age in the year 1098 of the Armenian era (1649 A.D.).

Signs and pictures:

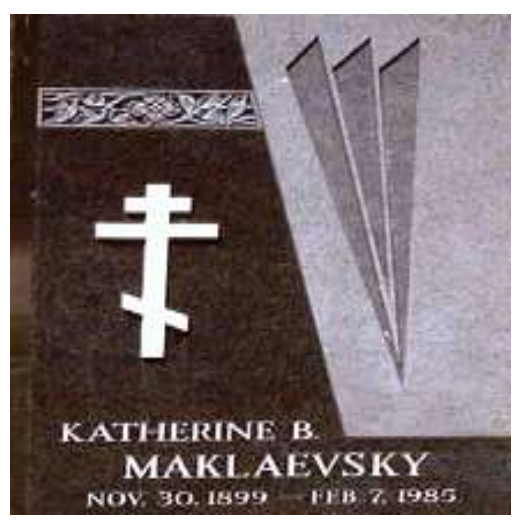

Figure 5.Russian Orthodox. Reprinted from American Monumental Company. Retrieved from

http://www.americanmonumental.com/russia n-orthodox.php Copyright 2008 American Monumental.

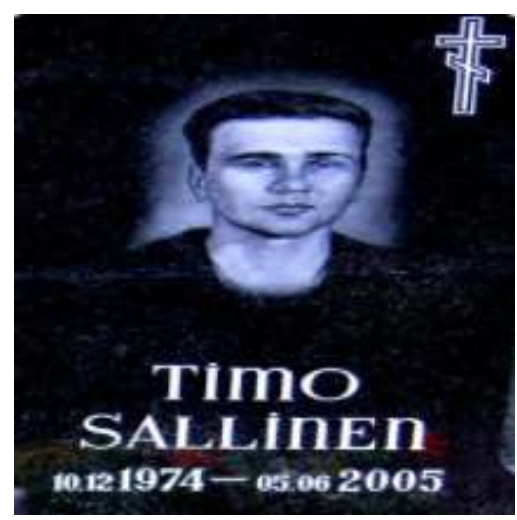

Figure 6. Hietaniemi Russian Orthodox Cemetery, Helsinki, Finland . Reprinted from http://www.candidanimal.com/2011/11/hiet aniemi-russian-orthodoxcemetery.html?view $=$ mosaic

\section{Catholic Tombstone Scripts}

In this faith also, in our examination we observed the two categories of representations: linguistic and nonlinguistic. A total of 747 occurrences of 10 themes in the linguistic representations were detected. As for the nonlinguistic category, both signs, and pictures and signs existed on tombstones. Table 5 illustrates linguistic and nonlinguistic representations with varying frequencies. 
Bada, E., \& Ulum, Ö. G. (2016). My culture is engraved on my tombstone. Journal of Human Sciences, 13(3), 5407-5422. doi: $10.14687 /$ jhs.v13i3.4246

Table 5

Expressions of Catholic Scripts

\begin{tabular}{|c|c|c|c|c|c|}
\hline Linguistic & & & Nonlinguistic & & \\
\hline Themes & ToM & $\%$ & Symbols & ToM & $\%$ \\
\hline Kinship & 404 & 54.1 & Signs & 24 & 63.0 \\
\hline Passing location & 268 & 35.9 & Pictures and Signs & 14 & 37.0 \\
\hline Occupation & 33 & 4.4 & Decorations & - & - \\
\hline Reasons of passing & 16 & 2.1 & Pictures & - & - \\
\hline Faith & 10 & 1.3 & & & \\
\hline Dwelling & 9 & 1.2 & & & \\
\hline Grief & 3 & 0.4 & & & \\
\hline Passing & 2 & 0.3 & & & \\
\hline Personality & 1 & 0.1 & & & \\
\hline Yearning & 1 & 0.1 & & & \\
\hline Total & 747 & 100.0 & Total & 38 & 100.0 \\
\hline Chi-Square (Asymp. Sig) & 0.000 & & 0.000 & & \\
\hline
\end{tabular}

From Table 5, we can clearly see that with a great dominance, the theme, kinship (54.1\%) in the linguistic category significantly outnumbered the existence of other themes: passing location $(35.9 \%)$, occupation $(4.4 \%)$, reasons of passing $(2.1 \%)$, faith $(1.3 \%)$, dwelling $(1.2 \%)$, grief $(0.4 \%)$, passing $(0.3 \%)$, personality $(0.1 \%)$, and yearning $(0.1 \%)$. In the nonlinguistic representation, a great majority of the symbols were signs $(63.0 \%)$ followed by pictures and signs $(37.0 \%)$. Samples from related tombstone scripts, and symbols are illustrated below:

Personality, grief, kinship: Erected by Thomas Morrison, in Fellend, in memory of his dutiful and affectionate daughter, Helen, spouse of James Gordon in Culvennan, who died February 17th, 1827, aged 22 years. Mourn for the mourners and not for the dead, for she is at rest, we are in tears. Also Penelope Morrison, his daughter, who died 28th Feb. 1892, aged 84 years.

Faith, passing location, kinship: God my redeemer of lives, And ever from the skies, looks down, and watches all my dust, 'Till he shall bid it rise. In memory of David Thompson, late of the excise, who died at Greenhill, 29 May 1841, aged 31 years. Mary, his daughter who died 12th June 1839, aged 2 years. Jane Mc Mieken, his mother, died 6th Feb. 1846, aged 72 years. David Thompson, his father, who died 1 st July 1846 aged 73 years.

Occupation, dwelling: Here lyes the body of Henry Sim from Allonby, Cumberland, fisherman at Tonguel and for 20 years or more, he died March 26th 1790, aged 55 years. Blessed at the dead which die in the Lord, for they rest from their labor's, and their works follow them.

Reasons of passing: In memory of Robert, son of John Rae, who departed this life 3rd Dec. 1815, in the fourth year of his age. Capt'n Robert Rae, his youngest son, who was lost at sea with ship crew and cargo, 16th March 1844, in the 18th year of his age. John his third son, died of consumption, 16th Jan. 1846, buried here. The said John Rae, died at Liverpool, 10th February 1866 aged 83 years, and is interred here. Janet McClure, wife of the said John Rae, died at Kirkcudbright, 7 th June 1876 aged 91 years.

Passing: Sacred to the memory of Richard Sproat, who died at Culquha, 12th April 1836, aged 81 years. Also of Margaret Sproat, his wife who died 5th Feb'y 1833, aged 67 years. Also of their children viz; Isabella, died 10th Janr'y 1821, aged 26 years. Barbara died 29th June 1821, aged 24 years. Also to the memory of Barbara Sproat, daughter of William Sproat, who died at Culquha, 8th 
Bada, E., \& Ulum, Ö. G. (2016). My culture is engraved on my tombstone. Journal of Human Sciences, 13(3), 5407-5422. doi: $10.14687 /$ jhs.v13i3.4246

November 1852, aged 1 month. All leveled by the hand of death, lie sleeping in the tomb. Also at Auchendolly of Cross Michael, 10th of Oct. 1869, Margaret daughter of William \&Marg't. Sproat, aged 17 years. Also the above William Sproat who died April 30th 1883, aged 77 years. Also Margaret his wife, who died March 13th 1892, aged 89 years. Also Alexander, their son, who died May 30th 1883, aged 37 years. Also William, their son, who died Jan'y. 24th 1884, aged 35 years.

Yearning: In loving memory of Matthew (Leo) Geoghegan. Died $28^{\text {th }}$ August 1985. Sadly Missed By His Loving Wife and Daughter.

Pictures and signs:

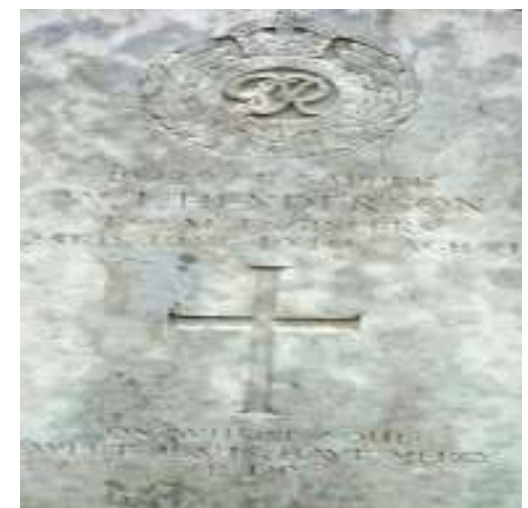

Figure 7. James, B. (2001). (Photographer). Tongland Churchyard - Inscription No.342. Retrieved from

http://www.kirkyards.co.uk/tongland/tongland.a sp?offset $=340$

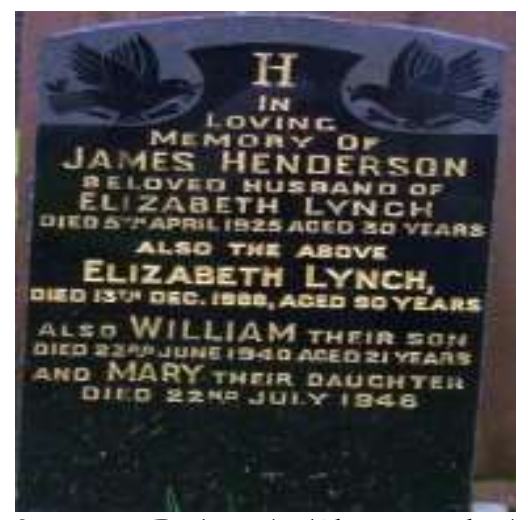

Figure 8. James, B. (2001). (Photographer). Tongland Churchyard - Inscription No.341. Retrieved from

http://www.kirkyards.co.uk/tongland/tongland.a sp?offset $=340$

\section{Protestant Tombstone Scripts}

In the examined Protestant tombstone scripts, the observed linguistic and nonlinguistic representations display a similarity to those previously observed in the Orthodox and Catholic tombstone contents, in that the theme kinship in the linguistic category was seen to be expressed rather more frequently compared to other themes. And, in the nonlinguistic category, similarly, signs were the most frequently occurring symbols. Table 6 displays the pertaining linguistic and nonlinguistic representations of Protestant tombstone scripts.

Table 6

\begin{tabular}{|c|c|c|c|c|c|}
\hline \multicolumn{3}{|l|}{ Linguistic } & \multicolumn{3}{|l|}{ Nonlinguistic } \\
\hline Themes & ToM & $\%$ & Symbols & ToM & $\%$ \\
\hline Kinship & 165 & 34.1 & Signs & 90 & 66.0 \\
\hline Faith & 135 & 27.9 & Decorations and Signs & 46 & 34.0 \\
\hline Dwelling & 52 & 10.7 & Decorations & - & - \\
\hline Passing location & 50 & 10.3 & Pictures & - & - \\
\hline Occupation & 38 & 7.9 & & & \\
\hline Grief & 17 & 3.5 & & & \\
\hline Personality & 10 & 2.1 & & & \\
\hline Reasons of passing & 7 & 1.4 & & & \\
\hline Passing & 5 & 1.0 & & & \\
\hline Untimely passing & 2 & 0.4 & & & \\
\hline Yearning & 2 & 0.4 & & & \\
\hline Affiliation & 1 & 0.2 & & & \\
\hline Total & 484 & 100.0 & Total & 136 & 100.0 \\
\hline Chi-Square (Asymp. Sig) & & & & 0.000 & \\
\hline
\end{tabular}


As can be observed from Table 6, in the linguistic category, kinship (34.1\%), with a majority of expression, was respectively followed by faith $(27.9 \%)$, dwelling $(10.7 \%)$, passing location $(10.3 \%)$, occupation $(7.9 \%)$, grief $(3.5 \%)$, personality $(2.1 \%)$, reasons of passing $(1.4 \%)$, passing $(1.0 \%)$, untimely passing $(0.4 \%)$, yearning $(0.4 \%)$, and affiliation $(0.2 \%)$. As for the symbols, signs were observed with $66.0 \%$, and decorations and signs with $34.0 \%$. Samples from related tombstone scripts reflecting the themes, and symbols are displayed below:

Kinship and dwelling: In memory of Eliza Melita. (Born Maltass) Widow of the late Frederick Hönischer. Died February 24, 1874. Aged 67.

Personality, grief, yearning, faith, occupation: Sacred to the memory of Charles Blunt ESQRE Whose mortal remains are interred under this stone Formerly of Woodford in the County of Essex H.B. Majesty's Consul for 8 years in Smyrna Having commenced his career as acting consul at Adrianople in 1832 Full consul at Salonica in 1835 and in Smyrna in 1857. A creditable, zealous faithful servant of her Majesty's government for 33 years. Leaving a widow and eight children to deplore. Their irreparable loss trusting with Christian resignation to the mercies of a blessed redeemer. For his eternal happiness and salvation. Born September 25 1800. Died 3 March 1864. Aged 64.

Passing location: To the memory of the Rev' W B Lewis. For nearly forty years British Chaplain at Smyrna. Died at old Brompton 3rd January 1870. Aged 72. His Mortal Remains Rest in Brompton Cemetary.

Reasons of passing: Sacred to the memory of Alfred Barker. ESQ of Leamington. Coventry. Warwick. He died of dysentery at Smyrna on the 20 day of April 1865 in the 26 year of his age.

Passing and untimely passing: Sacred to the memory of Gretchen Kreiter. Daughter of Henry and Clara Kreiter. Born August $8^{\text {th }} 1870$ Died January $26^{\text {th }} 1874$. Ere sin could blight or sorrow fade, death came with friendly care; the opening bud to heaven conveyed, and bade it blossom there.

Affiliation and yearning: Here lies buried one of Abraham's Raci, Baptist Yerushalmy of Constantinople, born of respectable parents, ..., regretted by many friends.

Decorations and signs:

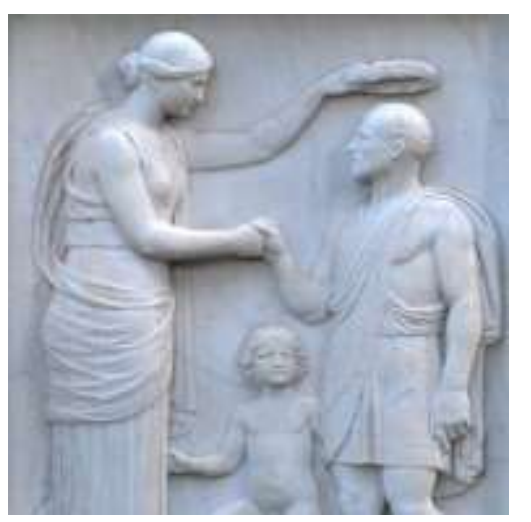

Figure 9. Cyron, M. (2012). (Photographer). Grave of Hans von Marées. Retrieved from https://en.wikipedia.org/wiki/Protestant Ce metery, Rome Copyright 2016 Wikipedia

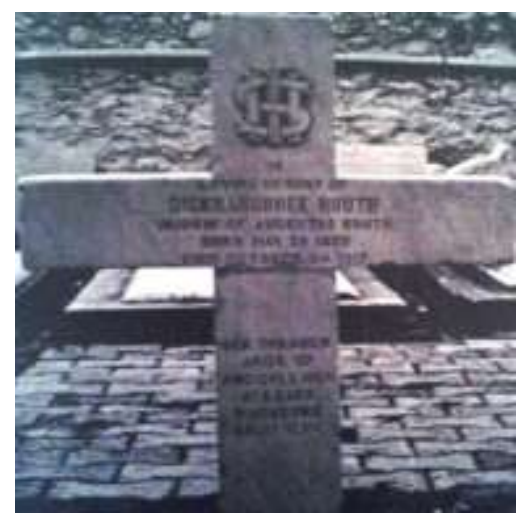

Figure 10. Dickranoohee Routh's Tombstone. Retreived from Gürman and Fitton-Brown, 2013, p.223. 

doi: $10.14687 /$ jhs.v13i3.4246

\section{Sunni Tombstone Scripts}

Besides similarities, the Islamic tombstones do also display some significant differences from those already examined. In the Sunni faith of tombstones, we can observe only linguistic representations. Nonlinguistic symbols, similar to the Taoist faith, do not appear on the gravestones. In Table 7 , we can see the emerged themes and their related percentage of occurrences.

Table 7

Expressions of Sunni Scripts

\begin{tabular}{llllll}
\hline Linguistic & & & Nonlinguistic & \\
\hline Themes & ToM & $\mathbf{0}$ & Symbols & ToM & $\%$ \\
Faith & 728 & 43.5 & Pictures and Decorations & - & - \\
Kinship & 251 & 15.0 & Pictures & - & - \\
Occupation & 136 & 8.1 & Decorations & - & - \\
Passing & 107 & 6.4 & Signs & - & - \\
Untimely Passing & 96 & 5.7 & & \\
Dwelling & 82 & 4.9 & & \\
Martyrdom & 70 & 4.2 & & \\
Reasons of Passing & 46 & 2.7 & & \\
Personality & 41 & 2.4 & & \\
Affiliation & 28 & 1.7 & & \\
Grief & 24 & 1.4 & & \\
Praise & 22 & 1.3 & & \\
Yearning & 17 & 1.0 & & \\
Social Status & 10 & 0.6 & & \\
Nicknames & 8 & 0.5 & & \\
Dynasty & 6 & 0.4 & & \\
Heroism & 3 & 0.2 & & \\
Total & 1675 & 100.0 & Total & \\
Chi-Square (Asymp. Sig) & 0.000 & & 0.000 & \\
\hline
\end{tabular}

From Table 7, we can clearly observe that the theme, faith, with $43.5 \%$, came on top of the list of other themes: kinship (15.0\%), occupation (8.1\%), passing (6.4\%), untimely passing $(5.7 \%)$, dwelling $(4.9 \%)$, martyrdom $(4.2 \%)$, reasons of passing $(2.7 \%)$, personality $(2.4 \%)$, affiliation $(1.7 \%)$, grief $(1.4 \%)$, praise $(1.3 \%)$, yearning $(1.0 \%)$, social status $(0.6 \%)$, nicknames $(0.5 \%)$, dynasty $(0.4 \%)$, and heroism $(0.2 \%)$. Samples from tombstone scripts reflecting such expressions are illustrated below:

Faith: Our dear Prophet states that believers do not die, they just move from the mortal life to eternal one. With the wish of prayer, mercy and forgiving. Son of Süleyman, Abdullah Nurullah".

Kinship and dwelling: "From Darende, Daughter of H. Bekir, Hatice Büyükkıdık, Al-fatiha for her soul. ?-1984.

Occupation and nicknames: Driver Baboş, Son of Selim Öneralan, Gül Ali and grandson Selim. Al-fatiha for their soul.

Passing and untimely passing: I was a rosebud not bloomed; Do not feel sad, as I found a better place to blossom. Al-fatiha for her soul. 1940-1958. 
Bada, E., \& Ulum, Ö. G. (2016). My culture is engraved on my tombstone. Journal of Human Sciences, 13(3), 5407-5422. doi: $10.14687 /$ jhs.v13i3.4246

Martyrdom: Son of Mustafa. Martyr policeman, Ali Okyay. Al-fatiha for his soul.1951-1984.

Reasons of passing: In the memory of young footballers passed away as a result of an accident on the way back playing away. Al-fatiha for their soul. Sami Bayraktar, Hakan Ece, Rafet Akkaya.

Personality: He is the very personification of honesty itself. Head of farm, Cello (refers to his nickname). Hasan Üsttaş. 1313-1989. Al-fatiha for his soul.

Affiliation: Member of Aliyemen Tribe from Sine Province. Son of Medrese teacher Mehmet, İbrahim İndirkaş. Al-fatiha for his soul.1877-1953.

Grief and yarning: You are a mortal, this life is enough, they said. This is your faith with no remedy, they said. But, how quickly I was left from my kids... Wife of Hasan, Ayşe Erez, Al-fatiha for her soul. 1921-1978.

Praise: This tomb belongs to blessed, martyr, great, honorable, in need of the mercy of great Allah and reading Semsu'd - Din Muhammed b. Ganem. Died in February, 1288.

Social status: From Ceyhan Notables, Son of Ferhat, H. Basri. Al-fatiha for his soul, 1925-1984.

Dynasty: 5th Vizier Cafer Pasha saw three emperors in his age and served for Sultan Sulleiman Han. His dignity and directorship went on till Selim Han. He reached Sultan Murad but couldn't reach his goal. On the way of luxuriant world, he found peace in eternity. With just one lack, his history was written hoping his eternal place would be paradise.

Heroism: Fighter of the War of Independence. Son of Hamamc1, Kadir Özlü. Al-fatiha for his soul.1901-1968.

\section{Alawite Tombstone Scripts}

Coming from the similar tradition, the Alawite tombstone scripts bear resemblances to as well as differences from the Sunni tombstones. For instance, in both, we can observe the theme faith to overwhelmingly outnumber the existence of other themes. However, while we could not observe any symbols on Sunni tombstones, the Alawite's were abundant with pictures and decorations. Table 8 presents the linguistic and nonlinguistic representations of Alawite tombstone inscriptions and symbols.

Table 8

\begin{tabular}{llllll} 
Expressions of Alawite Scripts & \multicolumn{5}{l}{} \\
\hline Linguistic & & & Nonlinguistic & \\
\hline Themes & ToM & $\mathbf{0}$ & Symbols & ToM & $\mathbf{\%}$ \\
Faith & 182 & 59.3 & Pictures and Decorations & 98 & 80.0 \\
Kinship & 86 & 28.0 & Pictures & 14 & 12.0 \\
Untimely Passing & 11 & 3.6 & Decorations & 10 & 8.0 \\
Occupation & 9 & 2.9 & Signs & - & - \\
Grief & 8 & 2.6 & & & \\
Passing & 5 & 1.6 & & & \\
Dwelling & 2 & 0.7 & & & \\
Reasons of passing & 1 & 0.3 & & & \\
Martyrdom & 1 & 0.3 & & & \\
Social status & 1 & 0.3 & & &
\end{tabular}


Bada, E., \& Ulum, Ö. G. (2016). My culture is engraved on my tombstone. Journal of Human Sciences, 13(3), 5407-5422. doi: $10.14687 /$ jhs.v13i3.4246

\begin{tabular}{llllll} 
Yearning & 1 & 0.3 & & & \\
Total & 307 & 100.0 & Total & 122 & 100.0 \\
\hline Chi-Square (Asymp. Sig) & 0.000 & & 0.000 & & \\
\hline
\end{tabular}

From Table 8, we can see that, the total occurrence of themes in the linguistic category is 307 , and similar to the Sunni, the theme, faith (59.3\%) topped the list of other themes: kinship (28.0\%), untimely passing (3.6\%), occupation (2.9\%), grief $(2.6 \%)$, passing $(1.6 \%)$, dwelling $(0.7 \%)$, reasons of passing $(0.3 \%)$, martyrdom $(0.3 \%)$, social status $(0.3 \%)$, and yearning $(0.3 \%)$. As for the nonlinguistic representations in the total 122 occurrences, with $80.0 \%$, pictures and decorations significantly outnumbered pictures $(12.0 \%)$ only, and decorations $(8.0 \%)$ followed suit. Samples from tombstone scripts reflecting these expressions, and symbols are illustrated below:

Faith and kinship: Wife of Ferit, SevimAr1c1.1940-2007. Al-fatiha for her soul.

Untimely passing and reasons of passing: Sait Dik, Al-fatiha for his soul. 1948-1981. I was happy on my work, but, they burnt me like a tinder, Without telling the reason. Once I reached safety at the age of 33, They destroyed my youth, Just before I was sated with it.

Occupation: Grocer. Haydar Özyedek. Al-fatiha for his soul.1326-1969.

Grief: Father of the father, our pains never end. Son of Ali, Tuncay Baltac1.1950-2011.

Passing: Mahiye Güler. Al-fatiha for her soul.1950-2013.Oh, my dark destiny, before blooming, and maturing, You made my world a dungeon, But left this world on my own desire.

Dwelling: From Diyarbakır, The son of Hüseyin, H. Emin Aybay. Al-fatiha for his soul.1898-1982.

Martyrdom: Martyr soldier, Suat Üstünolaner. Al-fatiha for his soul.1964-1984.

Social status: Sheikh, İbrahim Baykam.Al-fatiha for his soul.1904-1991.

Yearning: Mahbube Yağmurcu. Al-fatiha for her soul. Tell where you've gone, mummy. Your absence is such terrible....

Pictures and decorations:

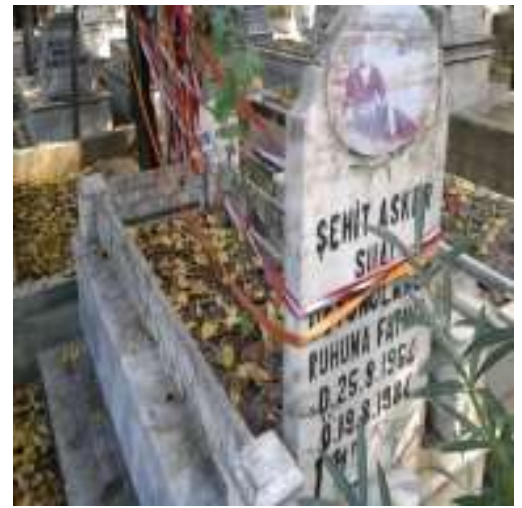

Figure 11. Bada \& Ulum (photographers). (2015). Suat Üstünolaner (1964-1984) Tombstone. Adana, Akkap1 Cemetary.

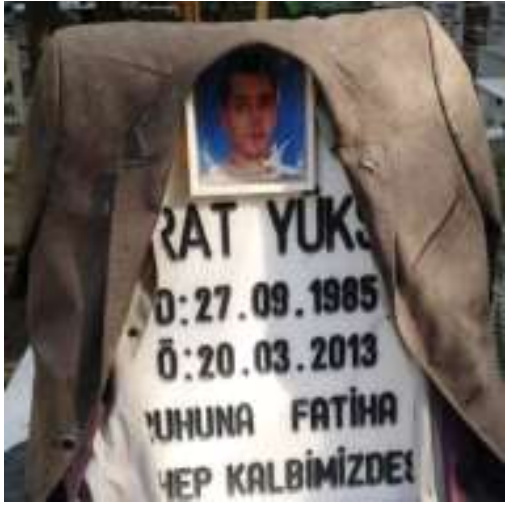

Figure 12. Bada \& Ulum (photographers). (2015). Murat Yüksel's (1985-2013) Tombstone. Adana, Akkapı Cemetary. 
Bada, E., \& Ulum, Ö. G. (2016). My culture is engraved on my tombstone. Journal of Human Sciences, 13(3), 5407-5422. doi:10.14687/jhs.v13i3.4246

\section{Discussion and Conclusion}

Having examined 2008 tombstones from diverse faiths, we discovered that each faith has its own specific characteristics as were reflected through the scripts and symbols on the gravestones. Besides such specificity, there are also commonalities, in that we see that each succeeding faith has been built upon a preceding one, and naturally, the eight faiths bear similarities as well as differences in transmitting linguistic and nonlinguistic representations to future generations.

The Shaman tombstone scripts revealed six linguistic themes and two nonlinguistic symbols. On the top of the list of this faith, comes affiliation followed by nicknames. And the symbols were pictures and decorations, and pictures only. As Winkleman (2013) states, affiliation and symbols are significantly treated in Shamanist tombstone inscriptions. The Shamanic traditions and beliefs cover the society's most important spiritual, religious, societal, and curative practices, providing a context to form a connection between an individual and a community. The fact that symbols were heavily employed on tombstone decorations is an indication of the Shaman culture in which communication is mostly in nonlinguistic forms and thus cannot be captured through texts only. For instance, Native American Indians are deeply spiritual and they communicated their history, thoughts and dreams from generation to generation through symbols.

Contrary to the Shaman faith, on the Taoist tombstones, three themes with relatively similar percentages assert themselves: dwelling, kinship and dynasty. The significance of hometown ties in Chinese community is well expressed by Chen (2002). In customary Chinese community, the family is another title for a parental tribe, covering not only its available representatives but also its forefathers held as sacred and honored in the tribe, and a number of feudal orders and moral codes among kinships related to Confucian principles (Sheng, 2004). As for nonlinguistic representation, no symbols were detected on the Taoist tombstones.

Similar to Taoist tombstones, kinship emerges as a very common theme in Judaist tombstone scripts. Besides the linguistic representation, nonlinguistic symbols were significantly used on Judaist gravestones. The Star of David existed on almost all tombstones. The Judaist family-roots of the Hebrew community are the seed of the following generations (Roiphe, 1986). "While courteous and loving relationships are the ground and aim of family, the family in Jewish society owns a holy aim beyond itself. That's to say, its aim is to bless, by means of living God's Word and Way, all facets of life. To sum up, the family is the main theme of Jewish world around which faithful observance works out" (Rosen, n.d.).

Being a common theme for all the Orthodox, Catholic, and Protestant gravestone inscriptions, kinship emerged with the greatest percentage of occurrence in the linguistic representation in these faiths. This theme was followed by race in the Orthodox, by passing location in the Catholic, and by faith in the Protestant gravestone inscriptions. This is no surprise as is well indicated in Timothy 5(8) in the Holy Bible that "anyone who does not provide for their relatives and especially for their own household has denied the faith and is worse than an unbeliever". For all three faiths, the emerging nonlinguistic representation is the symbol, Cross.

The Islamic tradition of tombstone representations is rather rich. In the Sunni scripts, faith comes as the most frequently expressed theme. The same also goes for the Alawites. In both faiths, the scripts on almost all tombstones invite the onlooker to pray on the soul of the deceased by reciting the Surah Al-Fatiha (The Opening). Although there is a set of dissimilarities between Sunni and Shiite or Alawite Islam, these Islamic sects own traditions, customs, beliefs, cultures, and doctrines in common (Blanchard, 2009). Kinship is the second most commonly occurring theme again in both the Sunni and the Alawite faiths. However, the overwhelming existence of nonlinguistic representation on the Alawite tombstones diverges from the Sunni tradition. This probably is due to the fact that the Anatolian Alawism is a thought and faith system affected by several beliefs and cultures, some of which are Shamanism, Judaism, and Catholicism, as well as the Greek culture, paganism, transmigration and mysticisms. As was stated previously, no faith is free from the influence of another, and each succeeding faith is built on an already existing one. Therefore, quite naturally, what was used before was carried over to the present. The symbols used 
on Alawite tombstones consisted of pictures and decorations, and pictures only. On a typical Alawite grave, one can see a picture of the deceased as well as a piece of cloth fitted onto or wrapped around the tombstone. According to Tuna (2000), after adopting Islam, the characteristics of former Turkish beliefs were mostly seen among Alawites. Although Alawism is cited as a sect of Islam, it has stronger relations with old Turkish beliefs and culture. Dhikir applications described as devotional actions in which brief phrases or prayers are recited silently or loudly in Islam for instance are seen in other forms in Shamanism as well.

In this study, we highlighted societal and cultural characteristics of different faiths as they are transmitted through tombstones. Our multi-faceted and detailed analysis uncovered an ever piling up cultural treasure lying in each tombstone script. With this regard, we see our study as an open ended process which provides support to prospective studies to be conducted in this field, since every new tombstone which has not been examined yet remains as a treasure box full of undiscovered cultural richness. The results obtained from this piece of research may prove to be significant for researchers in the field of culture, language and linguistics.

\section{References}

Bakırcı, N. (2005). Mevlevi Mezar Taşları. İstanbul: Rumi Yayınları.

Bernard, H. R., \& Ryan, G. (1998).Text analysis. Handbook of methods in cultural

anthropology, 613.

Beyatll, Y. K. (n.d.). Yahya Kemal Beyatll Eserleri. Retrieved on the $17^{\text {th }}$ of February, 2016 From http:/ / www.medeniyetimiz.com/index.php?option $=$ com content\&view $=$ article\&id $=282: \mathrm{n}$ idayi-sevim-mezar-talar-vazgecilmez-kueltuer-mirasmzdr\&catid $=60$ :genel\&Itemid $=78$

Blanchard, C. M. (2009). Islam: Sunnis and Shiites. Congressional Research Centre.

Carley, K. (1993). Coding choices for textual analysis: A comparison of content analysis and map analysis. Sociological methodology, 23, 75-126.

Chater, L. (2011). Armenian Graves, Inscriptions and Memorials in India. Dacca 1722-1977. Chater Genealogy Publishing.

Chen, Y. (2002). Chinese San Francisco, 1850-1943: A Trans-Pacific Community. Stanford University Press.

Chinese Cemetery Headstones (2009). Retrieved from http://chineseheritage.tripod.com/Creswick\%20Cemetery.htm

Chinese Tombstones (2007). Retrieved from http://houseofchinn.com/ChineseTombstones.html

Condillac, E. (2001). Essay on the Origin of Human Knowledge. Trans. Aarsleff, H. Cambridge, UK: Cambridge University Press.

Farber, J. L. (2003). Early American Gravestones: Introduction to the Farber Gravestone Collection. In American Antiquarian Society, 1-42.

Fernández, E. C. (2011). Euphemistic conceptual metaphors in epitaphs from Highgate Cemetery. Review of Cognitive Linguistics, 9(1), 198-225.

Frey, L., Botan, C., \& Kreps, G. (1999).Investigating communication: An introduction to research methods. (2nd ed.) Boston: Allyn \& Bacon.

Gürman, T. \& Fitton-Brown, S. (2013). İzmir-Buca All Saints British Protestant Church Atriumunda Yer Alan Mezar Taşları ve Lahitler. İstanbul: Arkeoloji ve Sanat Yayınları.

Headstones and Memorial Design Gallery (2015).Native American Cultural Monuments. Retreived on the $19^{\text {th }}$ of January, 2016 from http://www.monuments.com/culturalmonuments/native-american

Karamağaralı, B. (1972). Ahlatmezartaşları (Vol. 1). Kültür Bakanlığı Yayınları. Sanat TarihiDizisi $/ 19$.

Kaya, E. (2012). Ayasaluğ Bölgesinde Bulunan Beylikler Devri Mezar Taşları ve Kitabeleri. İstanbul: ZindeYayınevi. 
Bada, E., \& Ulum, Ö. G. (2016). My culture is engraved on my tombstone. Journal of Human Sciences, 13(3), 5407-5422. doi: $10.14687 /$ jhs.v13i3.4246

Kovala, U. (2002). Cultural Studies and Cultural Text Analysis. CLC Web: Comparative Literature and Culture, 4(4), 2.

Kut, G., \& Eldem, E. (2010). Rumelihisari şehitlik dergâhı mezartaşları. İstanbul: Boğaziçi Üniversitesi Yayınevi.

McKee, A. (2003). Textual Analysis: A Beginner's Guide. London: Sage.

Meier, A. (2013). Finding Hidden Stories in Tombstone Art. Retreived from http://hyperallergic.com/73763/finding-hidden-stories-in-tombstone-art/

Monumental Inscriptions at Tongland Kirkyard. (2015). Retreived from http://www.kirkyards.co.uk/tongland/tongland.asp

More $\begin{array}{llll}\text { Grave } & \text { Inscriptions } & \text { Retreived }\end{array}$ http:/ / www.chineselanguage.org/forums/viewtopic.php? $\mathrm{f}=6 \& \mathrm{t}=3685 \& \mathrm{kp}=20979$

Roiphe, A. (1986). The Jewish Family: A Feminist Perspective. Tikkun, 1(2), 70-75.

Rosen, R.D. (n.d.). The Family in Judaism. Past, Present and Future, Fears and Hopes. Retreived on the $25^{\text {th }}$ of January, 2016 from http://www.rabbidavidrosen.net/Articles/Judaism/Family\%20in\%20Judaism.doc

Sevim, N. (2010). Medeniyetimizin Sessiz Tanıkları Eyüp Sultan'da Osmanlı Mezar Taşları ve Ebedi Eyüp Sultanlılar. İstanbul: Erman Basım Yayım Dağıtım.

Seth, M. J. (1937). Armenians in India, from the Earliest Times to the Present Day: A Work of Original Research. Asian Educational Services.

Seyirci, M., \& Topbaş, A. (1985).Afyonkarahisar yöresi Türkmenmezartaşları (Vol. 2). İstanbul: Arkeoloji ve Sanat Yayınları.

Shapiro, G., \& Markoff, J. (1997). A matter of definition. Text analysis for the social sciences: Methods for drawing statistical inferences from texts and transcripts, 9-34.

Sheng, X. (2004). Chinese families. Handbook of world families.99-128.

Snell, K. D. (2003). Gravestones, belonging and local attachment in England 1700-2000.Past and Present, 97-134.

Stoke-on-Trent \& North Staffordshire, Hebrew Cemetery (2011). Retreived from http://www.jewishgen.org/jcr-uk/Community/stoke/headstone3.htm

Stone, G. (1991). Material Evidence of Ideological and Ethnic Choice in Long Island Gravestones, 1670-1800. Material Culture, 1-29.

Stone, G. (2009). Sacred Landscapes: Material Evidence of Ideological and Ethnic Choice in Long Island, New York, Gravestones, 1680-1800.Historical Archaeology, 142-159.

Streiter, O., Lin, A., Yen, K., Hsu, E., Wang, Y., \& Goudin, Y. (2008). Place Names on Taiwan's Tombstones: Facts, Figures, Theories. In Workshop on the relationship between the Distribution of Languages or Dialects in Taiwan and Racial Migration.

Streiter, O., Voltmer, L., \& Goudin, Y. (2007). From Tombstones to Corpora: TSML for Research on Language, Culture, Identity and Gender Differences. In PACLIC21, 21st

Pacific Asia Conference on Language, Information and Computation.The Holy Bible (n.d.). Responsibilities toward Others. Timothy, 5(8). Retreived on the $25^{\text {th }}$ of January, 2016 from www.gasl.org/refbib/Bible King James Version.pdf

Tuna E. (2000).Şamanlık ve Oyunculuk. İstanbul: Okyanus Yayıncilik.

Veit, R., \& Nonestied, M. (2008). New Jersey Cemeteries and Tombstones. Rivcrgate, New Brunswick, NJ.

Vırmiça, R. (2010). Kosova Tekkeleri Türbeleri ve Kitabeli Mezar Taşları. İstanbul: Sufi Kitap.

Winkleman, M. (2013). Shamanism in Cross-Cultural Perspective. Int J Transpers Stu, 31(2), 47-62. 